\title{
A Study of Affected Housselnolds"
}

Attitude towards the Mode of

Compensation for Land Acquisition in

Colombo-Kandy Alternative Highway

Project

S.H.U. De Silva

$121 \mathrm{AAY} / 20014$ 


\title{
A Study of Affected Households' Attitude towards the Mode of Compensation for Land Acquisition in Colombo-Kandy Alternative Highway Project
}

Dissertation Submitted to the University of Sri Jayewardenepura as a Partial Fulfillment for the Requirements of the Final Examination of the M.Sc. in Real Estate Management and Valuation Degree

\author{
Full Name : Senarathna Hudson Udayakumara de Silva \\ Examination No : REMV/54 \\ Registration No : GS/M.Sc./REMV/3406/08 \\ Department : Department of Estate Management and Valuation \\ University : University of Sri Jayewardenepura \\ Date of Submission : May 6, 2014
}




\section{Student's Declaration}

The work described in this dissertation was carried out under the supervision of Mrs. N.C. Wickramaarachchi and any report on this has not been submitted in whole or in part to any university or any other institute for another degree /examination or any other purpose.

S.H.U. De Silva

Index No. REMV/054

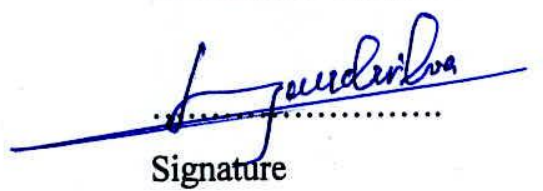

06.05 .2014 


\section{Supervisor's Declaration}

Hereby, I certify that Mr. S.H.U. De Silva. (Registration No: GS/ M.Sc./ REMV/ 3406/ 08) duly completed the research titled "An Analysis of Possible Issues Faced by "Affected households' attitude towards the mode of compensation for Land Acquisition in Colombo - Kandy Alternative Highway Project" under my supervision and recommended to submit for the evaluation.

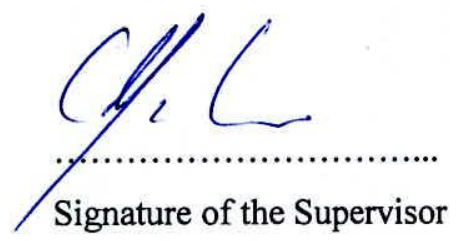

Signature of the $2^{\text {nd }}$ examiner

Signature and the official stamp of the Head 


\section{Acknowledgement}

There are many people to acknowledge. Firstly, I would like to acknowledge the very kind help and valuable direction received from my supervisors Mrs. Padma Weerakon and Mrs. N.C.Wickramarachchi (Senior Lecturers, Department of Estate Management and Valuation). Without their necessary guidance, support and advice allocating your precious time to guide me, this would have been not done.

I am grateful to my "Research Methods for Management" lecturers, Senior Professor (Dr.) H.H.D.N.P. Opatha and Professor R.G. Ariyawansa (Department of Estate Management and Valuation) for their contribution in laying foundation for researching.

I wish to extend my special thanks to other lecturers who were immensely benefited by the continents and suggestions offered. Mr.W.H.T. Gunawaradhana (Tutor, Department of Estate Management and Valuation) and for his great guidance in statistical analysis.

I express my gratitude to the staff of the Environmental and Social Development Division of the Road Development Authority.I would like to take this opportunity to thank all the resource persons and friends who contributed in participating interviews for primary data collection and without your help it had not been successful this research work.

My sincere thanks are due to parents, my friends, staff members and my family members to make this research successful. The Department of Estate Management and Valuation, University of Sri Jayawardhanapura for their wonderful support given to fulfill my task successfully. Finally I would like to remember all the persons whose names are not mentioned here but contributed in many ways for the dissertation.

Thank you.

\section{S. H.U. De Silva}




\section{Table of Contents}

ACKNOWLEDGEMENT

TABLE OF CONTENTS ii

LIST OF TABLES iv

LIST OF FIGURES vi

LIST OF ABBREVIATIONS vii

ABSTRACT viii

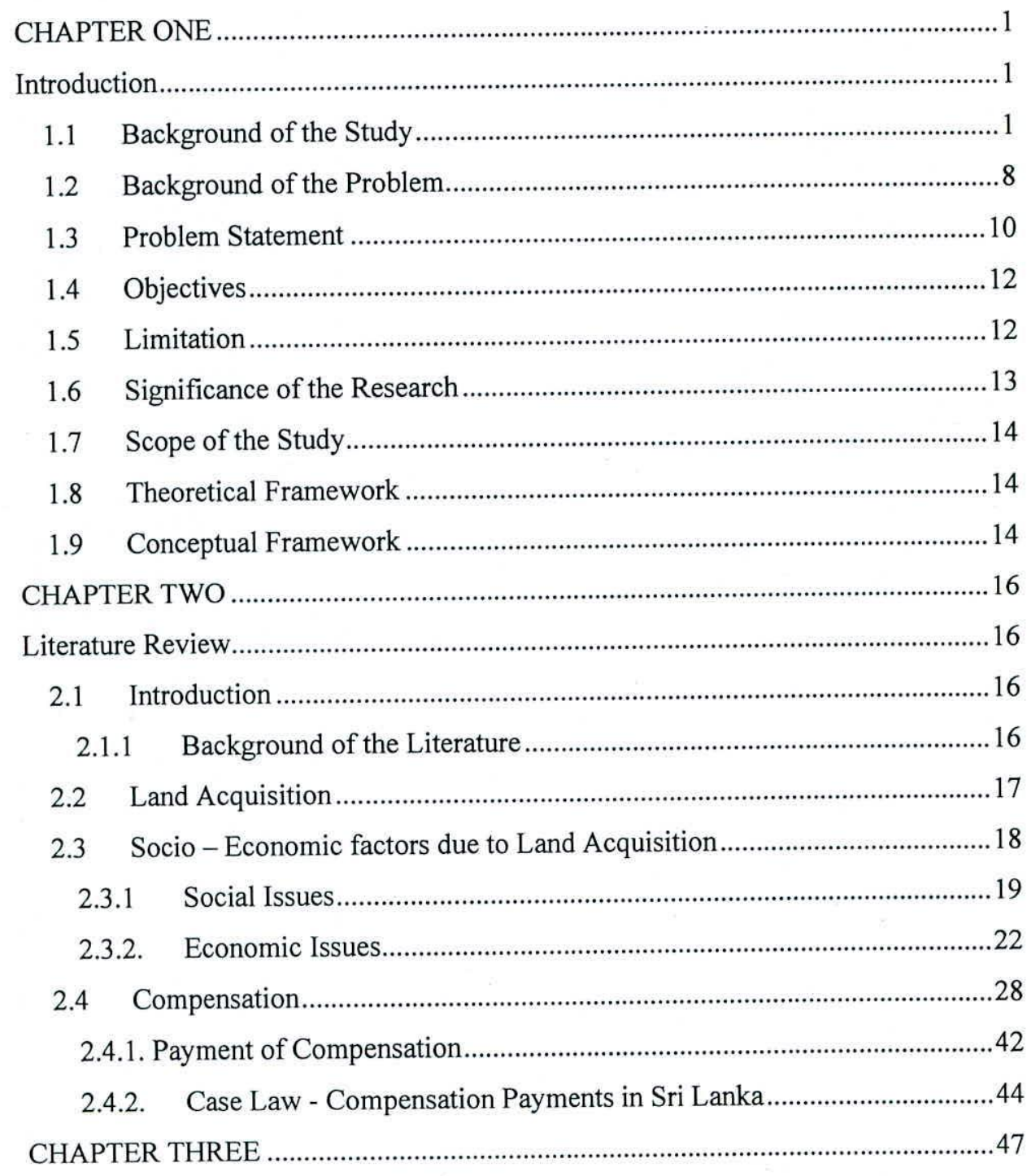




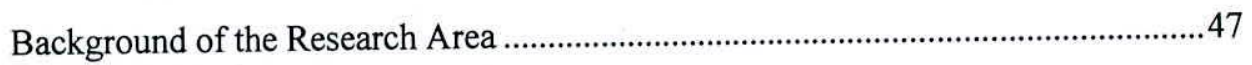

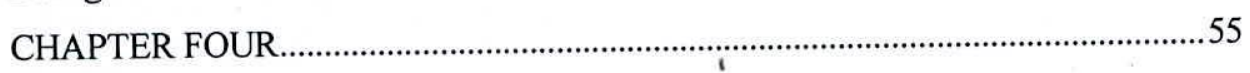

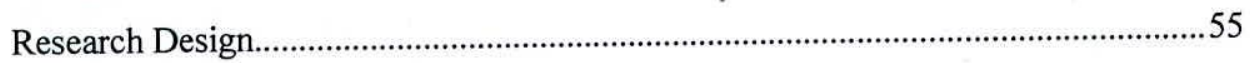

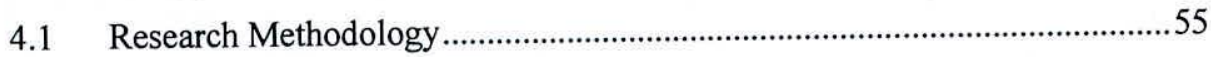

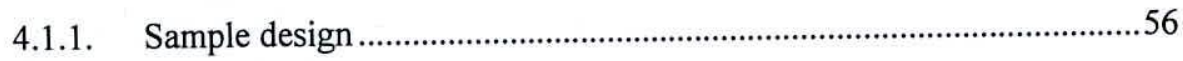

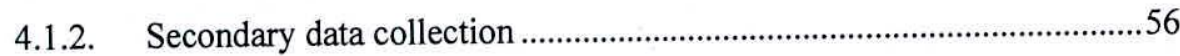

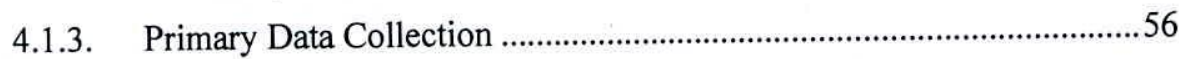

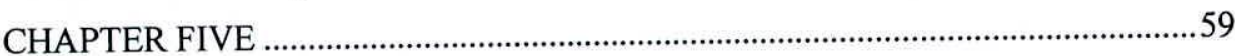

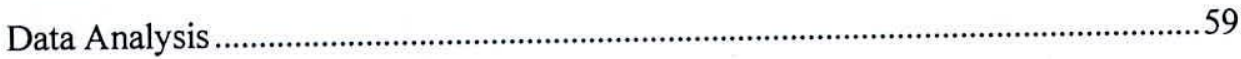

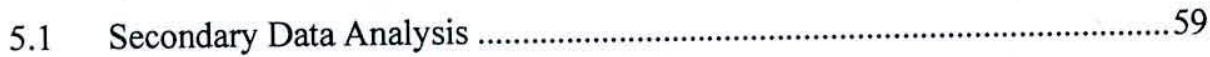

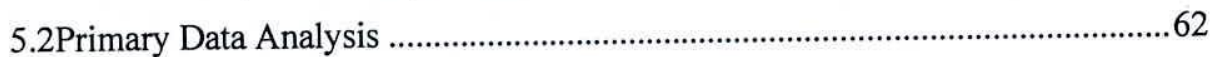

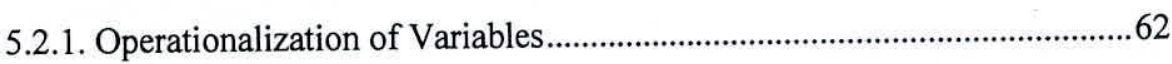

5.2.2 Validation of Measurement Properties ........................................................63

5.2.3. Cross Tabulation ....................................................................................

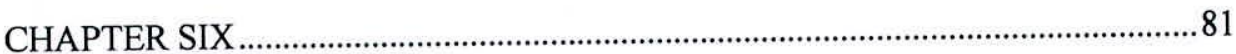

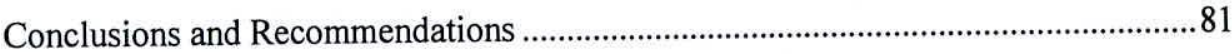

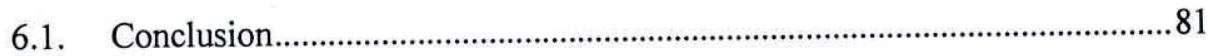

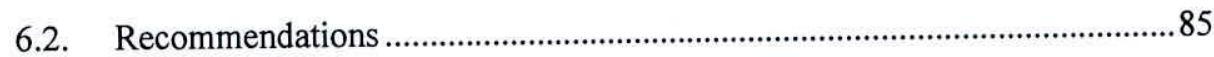

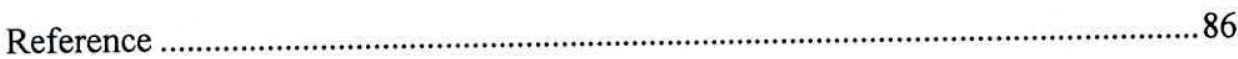

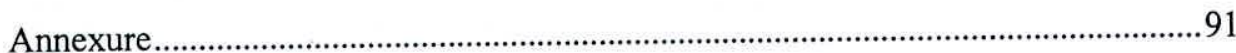

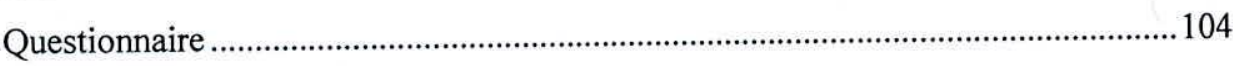




\section{LIST OF TABLES}

\section{TABLE}

PAGE

Table 3.1: Total Grama Niladari Divisions

Table 3.2: Total Population in Gampaha District 51

Table 3.3: Gampaha Divisional Secretariat Division $\quad 51$

Table 3.4: Employment Details $\quad 52$

Table 3.5: Mahara Divisional Secretariat Division 52

Table 3.6: Employment Details 53

Table 3.7: Biyagama Divisional Secretariat Division $\quad 53$

Table 3.8: Employment details $\quad 54$

Table 3.9: Grama Niladari Divisions of affected Divisional Secretariat

Table 5.1: Summary of Land Acquisition/Resettlement Impacts 59

Table 5.2: Private Structures by Type of Structures and Degree of Impact 61

Table 5.3: Divisional Secretariat Division 62

Table 5.4: Areas 63

Table 5.5: Compensation Issues $\quad 64$

Table 5.6: Landholding Status $\quad 65$

Table 5.7:KMO and Bartlett's Test: Compensation-Loss of Land 66

Table 5.8:KMO and Bartlett's Test: Compensation - Adaptability new
location

Table 5.9:KMO and Bartlett's Test: Compensation- Loss of Business 66

Table 5.10:KMO and Bartlett's Test: Compensation - Affect to personal
transport system

Table 5.11:: Reliability Statistics $\quad 67$

Table 5.12:: Item-Total Statistics $\quad 68$

Table 5.13: Reliability Statistics $\quad 68$

Table 5.14:Item-Total Statistics $\quad 69$

Table 5.15: Reliability Statistics $\quad 69$

Table 5.16:Item-Total Statistics $\quad 70$

$\begin{array}{ll}\text { Table 5.17: Descriptive Statistics } & 70\end{array}$

Table 5.18: Comparison of Current income and Future expected income $\quad 75$

Table 5.19: Cross Tabulation of Income from Affected Land hold against
Extent of Income Loss

Table 5.20: Cross Tabulation of Landholding status against Land Use 77

Table 5.21: Cross Tabulation of Landholding status against Land Use 78 
Table A.1:Total Variance Explained: Compensation-Loss of Land 91

Table A.2:Total Variance Explained: Compensation- Loss of Business 91

Table A.3:Total Variance Explained: Compensation - Adaptability new
location

Table A.4:Total Variance Explained: Compensation - Affect to personal
transport system

Table A.5:One-Sample Statistics $\quad 93$

Table A.6:One-Sample Test 93

Table A.7:One-Sample Statistics $\quad 94$

Table A.8:One-Sample Test 95

Table A.9:One-Sample Statistics 96

Table A.10:One-Sample Test $\quad 97$

Table A.11:One-Sample Statistics $\quad 99$

Table A.12:One-Sample Test $\quad 99$

Table A.13:Case Processing Summary 101

Table A.14:Cross Tabulation: Mode of Compensation against loss of land in
districts

$\begin{array}{ll}\text { Table A.15:Chi-Square Test } & 102\end{array}$ 


\section{LIST OF FIGURES}

\section{FIGURE}

PAGE

Figure 1.1 - Economic and Social Issues due to land acquisition for Development

Figure 1.2 - Conceptual Framework 14

Figure 3.1 - Proposed Road $\quad 48$

Figure 3.2 - Study Road Area $\quad 49$

Figure 3.3 - Location Map of Colombo $\quad 50$

Figure 5.1 - Land Loss In Gampaha Divisional Secretary Division 74

Figure 5.2 - Land Loss In Mahara Divisional Secretary Division 75

Figure 5.3 - Land Loss In Biyagama Divisional Secretary Division 75

Figure 5.4-Comparison between expected compensation payment, current income, expected income after resettlement, Agricultural land losses and other types of losses to households 


\begin{tabular}{ll} 
& \multicolumn{1}{c}{ Abbreviations } \\
& \\
ADB & - Asian Development Bank \\
AP & - Affected Persons \\
BOI & - Board of Investment of Sri Lanka \\
CKAH & - Colombo - Kandy Alternative Highway \\
CNS & - Corridor North-South \\
DPs & -Displaced Persons \\
DS & -Divisional Secretariat \\
ESD & -Environmental and Social Development Division \\
GND & - Grama Niladari Divisions \\
LAA & - Land Acquisition Act \\
LARC & - Land Acquisition Resettlement Committee \\
NIRP & - National Involuntary Re-Settlement Policy \\
OCH & - Outer Circular Highway \\
PEA & -Protect Executing Agency \\
RAP & - Resettlement Action Plan \\
RDA & - Road Development Authority \\
RPs & -Resettlement Plans \\
U.K. & - United Kingdom \\
WB & - World Bank
\end{tabular}




\begin{abstract}
Acquisition of Lands for public purpose leads to many issues of local residents of the development area. In particular the acquisition takes place when there is a public purpose to fulfill. With the fulfillment of public purpose the outcome will result is a benefit to the public. Land acquisition is a result of massive infrastructure development which is in progress along with the result of rapid increase of population, urbanization and transition. This will raise the living standards of its people through sustainable development. Looking at opportunities to maximize the public benefit government considers development opportunities at right time and phase will result in the economic growth of the country. Literature shows that there are different types of common issues such as social and economic with respect to the compensation based on land to land or money to land faced by residents due to acquisition of lands in different countries. The main purpose of this study is to analyze possible issues faced by households due to land acquisition and categorize issues. Issues faced by the residents were analyzed to identify the possible issues and categorized accordingly.
\end{abstract}

There are many researches that have been carried out in this thematic area. Mixed method of data collection was applied in this study. The survey was focused to collect information on opinion of affected parties. Unit of analysis was community who faced social and economic issues relating to the mode of compensation. A total population of 827 affected people was considered as the sample covering the areas of Gampaha District and 3 areas were employed for this purpose. Total population used as a sample size and the analysis was done using Statistical Package for Social Science (SPSS) computer software. Structured interviews were held to ascertain their opinions on steps whichever necessary to identify the possible issues including socio-economic and demographic variables. Findings of the study indicate that agricultural land holders are losing their income and attitude towards the compensation is land to land.

Key Words: Land Acquisition, Issues of Socio-Economic and Demographic Variables 


\section{CHAPTER ONE}

\section{Introduction}

\subsection{Background of the Study}

The land is a scarce natural resource and one of the main factors of production for human activities. When a development take place the land pays a major role. No development with the land can take place without a proper property rights.

The adverse consequences resulting from land acquisition for public purposes have become a worldwide issue with the social and economic aspects which attracts growing public interest and concern. International development agencies and national governments have adapted policies and practices to mitigate or minimize these consequences if they can't be avoided. At present, in Sri Lanka a huge investment is made annually for road development, for example Rs.133.7 billion in year 2012 requiring a large extent of land from the public (Annual Report - CBSL, 2012). In addition, modern roads constructed by the Road Development Authority need construct roads wider than the roads constructed in the past and hence they need more land and space. As most of the road projects are improvements and rehabilitation of existing roads going through densely populated developed areas, a large number of people are affected by land acquisition. As a result, while a colossal amount of funds requires for compensation payments for road development projects, an increasing number of people are becoming adversely affected victims of the road development.

In 2010, the economic infrastructure development program of the government focused on all areas of infrastructure including development of roads supporting a regionally balanced economic growth (Annual Report - CBSL, 2010).

According to the Work Bank (1996) $84 \%$ of total lands are owned by the government of Sri Lanka. $43 \%$ of the lands used for Agricultural purposes which covered about 2.79 million Hectares. Out of this about $53 \%$ are owned by the government. Though 
A Study of Affected Households' Attitude towards the Mode of Compensation for Land Acquisition in Colombo-Kandy

there are many lands owned by the government, it is essential to acquire lands for the development purpose.

In order to solve the land supply, the government use acquisition as a tool for development projects. Hence land acquisition is a way out to solve problems with land ownership and land owners reluctance to offer their lands for development projects.

Land acquisition can be defined as the acquisition of ownership of private property by the government on behalf of the public using special acquisition governing laws, for the use of the community. Sometimes, the expressions "expropriation" and "compulsory purchase" are also used to mean such transfer of ownership of a land.

The principle that governs for the land acquisition is payment of compensation to the land owner no better off or worse off. Therefore reasonable compensation has to be made to the owner of the land when pay the compensation by the government. This payment of compensation is a question in most of the time and there are grievances by land owners saying mode of compensation is not satisfied due to reasons of insufficient amount of compensation or not filling the requirement they used to enjoy before acquisition. This is part of the other issues faced by them and also can be considered as one of the major issue.

It is argued that the land originally belonged to the community at large, and therefore, what is being achieved through compulsory acquisition is just an attempt to reach the status ante. The community is merely taking over what belonged to the community.

Compulsory Purchase laws were enacted in Sri Lanka when the Land Acquisition Ordinance No.3 was passed in 1876. This was more similar to the Land Clauses Consolidation Act of 1845 prevailing in U.K. at the time. Also this has similarities to Indian Land Acquisition Act. When the land is needed for public purposes, the practice was governor called for a report from the Surveyor General. Thereupon the Government Agent notified through the Government Gazette, the intention of acquires the land and called for claims. A summary inquiry as to the value of the land 
and amount of compensation was then made, followed by a tender of compensation to the owners (Gorden, 1938).

The compensation has suggested through different forms which were land to land or land to money. Land to land compensation took place, when the government decided to re-settle families to government identified lands. Then the owners of land did not have any option other than accepting the government allocation. Other than the said the most common method of compensation is cash grants for the value of the land acquired. This method has a long procedure and the compensation has to be paid on the basis of Market Value. If there are any further damages, the land owner has a right to claim for the damaged occurred. This can be seen as universal issue which has not settled. In Sri Lanka, the compensation is paid through several laws. Those are Land Acquisition Act (LAA) No. 9 of 1950, Land Reform (Special Provinces) Act No.14 of 1986, Urban Development Authority Law, No.41 of 1978, National Housing Development Authority Act, No.17 of 1979, Mahaweli Authority of Sri Lanka Act, No 23 of 1979, Walawe Land Act,No.11 of 1958, Town planning Schemes, Colombo District (Low Lying Areas) Reclamation and Development Board Law No.15 of 1968, Non Performing Organization Act 11 of 2011, Greater Colombo Economic Commission (GCEC) Act, No.4 of 1978, Ceiling on Housing Property Act, No.1 of 1973. However, for special circumstances, "Cabinet Papers" have been submitted by Cabinet Ministers to pay additional compensations other than the Land Acquisition Act by setting up of "Land Acquisition and Resettlement Committees". This is confirmed the further payment of additional compensation than the existing payment methods.

Other than the compensation, there are several consequences arose due to land acquisition. International development agencies and developed countries have adopted adequate social safeguard policies, administrative procedures and practices to avoid or mitigate adverse impacts caused by land acquisition. The global obligation towards social safeguard issues has bearings on the United Nation Convention on Universal Declaration of Human Rights (1948) and subsequent human right conventions adopted by European Economic Commission (European Convention of Human Rights, Article 1 protects private possession, 1998). Similarly, the adherence 